\title{
Tőkepiaci unió vagy szabadságharc?
}

\begin{abstract}
Az Európai Unió válságkezelése során egy sor új, nemzetek feletti szabály és eljárás jött létre, mindenekelőtt a költségvetési és bankuniónak nevezett intézkedési együttes. Ezek már ma is a közös költségvetés hétévi összegénél nagyobb érték felett rendelkeznek, ráadásul a rendszerszinten meghatározó pénzintézetek közös felïgyelet és szabályozás alá kerültek. A 2019 novemberéig hivatalban lévő Bizottság is szorgalmazta, hogy még mandátumának lejárta előtt kerüljön sor a 2014 óta működő bankunió tőkepiaci unióval történő kiegészítésére. Ezek az újítások értelemszerüen csak az euróövezet tagjait érintik. A valutaunión kívül rekedtek - így a visegrádi államok és a skandinávok - számára marad a „szabadságharc”, a döntési hatáskörök védelme, párhuzamosan a védőháló elutasításával.* Journal of Economic Literature (JEL) kód: F15, F02, G18, G21.
\end{abstract}

Az Egyesült Királyság egy ma még vitatott hosszúságú és tartalmú átmeneti időszakot követően kiválik az Európai Unióból. A maradék Európa jogi értelemben is egységesebb lesz, a gazdasági modellek tekintetében pedig ma már csak az írek képviselik a tőzsdei kapitalizmust az unióban. A 2008-2009. évi pénzügyi válságot követően az EU a bankok, a pénzintézetek és a tőkepiac közösségi irányítása irányába indult el; mi több, a tőkepiacok közösségiesítése ma már nem pusztán elméleti lehetőség, hanem olyan konkrét szabályozási program, amelyen az uniós intézmények munkálkodnak. ${ }^{1}$ A Bizottság 2018. májusig 12 jogszabálytervezetet terjeszt elő e témában, amit szándéka szerint a Tanácsnak és az Európai Parlamentnek még 2019 során véglegesítenie kellene. Az intézkedés a határokon átnyúló beruházások egységes szabályozásával, mindenekelőtt a kötvénypiac megteremtésével a Bizottság becslése szerint 2,1 ezermilliárd

\footnotetext{
* Köszönettel tartozom a kézirat névtelen lektorának alapos és lényegi észrevételeiért, a fennmaradó hibák csak a szerzőt terhelik.

${ }^{1}$ EC [2015a] vitával és kiegészítő anyagokkal, valamint EC [2015b]. A források mind a joghatályos dokumentumokat, mind a részletes intézkedési terveket tartalmazzák, és könnyen hozzáférhetők, így nem ismertetjük részleteiket.
} 
(sic!) eurónyi tőke ${ }^{2}$ mozgását érinti, és kézzelfoghatóan új minőséget jelent az európai integráció elmélyítésében. Mivel e kiterjedt joganyagnak alig negyedéről egyeztek meg a tagállamok e cikk lezárásának idején, elsietettnek tartanánk, ha elemzésünk a technikai és szabályozási részletekre összpontosítana. Annál is inkább, mert a Bizottság és a tagállamok álláspontja gyakran eltér, és a köztük létrejövő kompromisszumokat - beleértve a Tanács határozatait - az Európai Parlament még lényeges pontokon felülírhatja. Ugyanakkor stratégiailag megkerülhetetlen, hogy jelentőségének megfelelően idejekorán szót ejtsünk az európai integráció új minőségét jelentő tőkepiaci uniós kezdeményezésről az integrációelmélet és a kimaradó tagállamok gazdaságpolitikája szempontjából - ez a most következő írás tárgya.

Ez a szabályozási lendület része annak a politikai folyamatnak, amely - az öt elnök 2015. júniusi jelentésétől (EC [2015c]) Emmanuel Macron 2018. tavaszi felvetéséig az európai integráció elmélyítésére irányuló számos konkrét kezdeményezést jelent. E felvetések része, hogy az érdekeltek akkor is elörelépnek, ha mások ebből kimaradnak, vagyis a többsebességes integráció formalizálódik. Értelemszerűen ezért az a központi kutatási kérdésünk, hogy mit tehetnek érdekeik védelmében a páratlan léptékủ mélyülésből - bármi okból - kimaradók vagy kihagyottak. A napi politikában a „Brüsszellel szembeni szabadságharc” és az „unortodox politika” hívószavai alatt megjelenő érdekérvényesítési törekvések lehetőségei és korlátai állnak tehát a középpontban. Utóbbiak a magyar, a lengyel, a cseh, a svéd és a dán politika számára bizonyára lényegesek. Mi több, ezen áll vagy bukik az, hogy a két- vagy többsebességes Európa a korábbiakból már ismert változó geometria vagy inkább a vonat első- és másodosztálya szerinti különbségtételt eredményezi-e majd. ${ }^{3}$

Nem kérdéses, hogy ez az egyszeri esemény egybeesik az Európai Unió 2020 utáni többéves pénzügyi keretének kidolgozási munkálataival, és ennek összefüggésében elkerülhetetlenül előtérbe kerülnek a „hogyan tovább?” stratégiai kérdései, amelyek túlmutatnak a szokásos nettó adok-kapok bazári alkuján. A Bizottság 2017. júniusi, öt változatban előadott elképzelése (például EB [2017], EC [2017b]), valamint az azóta is számos - nemzeti és közösségi - fórumon folyó műhelymunka révén már eldördült a startpisztoly. Az Európai Unió már ma is láthatólag egyre kevésbé a hagyományos mezőgazdasági és területfejlesztési támogatások ügyéről szól. A korábban háttérbe szorított nagy, kellemetlen kérdések vetődnek fel: a rendőrségi és igazságügyi együttműködés a tömeges és szabályozatlan bevándorlás miatt, a kül- és biztonságpolitika a posztszovjet és a földközi-tengeri térség válsága miatt, végül a pénzügyi integráció elmélyülése és ennek szabályozása.

Kiindulópontunk, hogy a britek kilépése az általunk taglalt kérdések mindegyikében, de különösen a pénzügyi unió és a makroprudenciális szabályozás terén új lendületet adhat a jórészt már elindult egységesítési folyamatoknak (Macchiarelli [2017] 110-111. o.). Létrejött az esélye a „valódi gazdasági és pénzügyi unió” kialakításának. Ennek a lényege az, hogy az eddig csak megtürten, átmeneti, pragmatikus

\footnotetext{
${ }^{2}$ Ez a 2020 és 2027 közti időszakra várható közösségi költségvetés értékének 2500-szorosa.

${ }^{3}$ Románia és Bulgária hivatalosan napirendre vette a közös valuta bevezetését, ezért náluk inkább a „mikortól” a kérdés, semmint az, hogy mi lenne a kimaradás ára.
} 
megoldásként létező nemzetek feletti megoldások politikai és jogi elismerést is nyernek. ${ }^{4} \mathrm{Mi}$ több, a bankunió még befejezetlen elemei - mindenekelőtt a közös betétbiztosítás - és a költségvetési átláthatóság intézményesítése, a statisztikai kimutatások szigorúbb ellenőrzése, az elszámolási trükkök visszaszorítása a magától értetődő feladatok közé sorolhatók. Egyre kevésbé lesz tartható az az egyébként a korábbi időszakban is hamis megközelítés (Bajusz [2015]), amely a nettó transzferegyenlegek alapján értelmezte az Európai Uniót. Nem ellenszolgáltatás fejében kell a szabályokat követni, hanem a müködőképességhez füződő önérdekből.

\section{A költségvetési egyezmény elvei és a tagállami költségvetési gyakorlat}

A tagállami költségvetési politika keretét a 2012-ben elfogadott és 2014 óta hatályos költségvetési egyezmény ${ }^{5}$ szabályozza. Ez lényegében megerősíti a korábbi stabilitási és növekedési egyezményt, de több helyütt pontosítja és szankciókkal is megtámogatja ezt (Csaba [2014]). Kétségtelen, hogy nem a büntetéstől való félelem, hanem a gazdasági növekedés visszatérte magyarázza azt, hogy 2014 és 2018 közt az euróövezet egészének és a legtöbb tagállamnak a költségvetési fenntarthatósági mutatói javultak.

Más a helyzet az elméletben, ahol a fenti egyezmények ortodoxiáját meghaladottnak tekintik, és a neokeynesi iskola határozza meg a gondolkodás fö csapásirányát. A világáramot képviselö áttekintés (Blanchard és szerzőtársai [2016]) elsősorban az Egyesült Âllamok példáján vizsgálja a szerzők által „új normalitásnak” nevezett világot. Ebben az államháztartási stimulus korántsem egyszeri és rövid távú, hanem tartós, a közpénzügyi hiány jelentős mértékben természetes, az államadósság pedig soha nem látott mértéküre duzzadhat. Ebben a világban megfér a várakozásokból eredeztetett tartós deflációs veszély és az ez ellen tartósan negatív kamatokkal operáló jegybanki gyakorlat. Ekkor a jegybanknak nem feladata sem a megtakarításoknak a bankrendszerbe terelése, sem pedig a tőke- és az árupiacokon ilyenkor kialakuló eszközárbuborék kipukkasztása.

A Fed láthatólag a munkanélküliség természetes rátájának elérése után sem törekszik a korábbi időszakban megszokott kamatszintek elérésére. Mi több, a Trump elnöksége alatt véghezvitt adócsökkentés és a Dodd-Frank-féle, 2010. évi tőkepiaci korlátozások 2017. évi visszavonása együttesen még tovább fújja a befektetési léggömböt.

A gyakorlat művelői által jegyzett párhuzamos kötet - Ódor (szerk.) [2017] - az európai tapasztalatokat összegezve indítja el a helyzetértékelést. Kiemelkedően fontos szerepet kap az a tény, hogy a jegybankok mérlegföösszege - főképp, bár nem kizárólag a bankmentések következtében - a GDP-hez képest jelentősen megnőtt. ${ }^{6}$ Ez megnövelte a monetáris és lecsökkentette a költségvetési politika mozgásterét.

\footnotetext{
${ }^{4}$ Feltételeit könnyű felsorolni, de annál nehezebb gyakorolni (Halmai [2018a]).

${ }^{5}$ Treaty on Stability, Coordination and Governance in the Economic and Monetary Union.

${ }^{6}$ A Fed esetében ez nem kevesebb, mint négyszeres (sic!) volt egyetlen évtized alatt. Ennek körülményeiről, az idevezető döntésekről és értelmezésükről kimerítő áttekintést ad a központi bankot ekkortájt vezető Ben Bernanke magyarul is napvilágot látott emlékirata (Bernanke [2017]).
} 
Az említett kötet szerzői jelentős teret szentelnek a költségvetési politika depolitizálásának, az ezzel kapcsolatos törekvések életszerűségének. Rámutatnak arra, hogy a költségvetési területet - szemben a jegybankkal - sosem sikerült depolitzálni, bármi is a költségvetési tanácsok hatásköre. Ódor-P. Kiss [2017] részletes elemzéssel mutatja ki, hogy a költségvetési politikát egyre összetettebb és részletesebb elöírások és szabályok kötnék, mind országokon belül, mind az Európai Unióban. Ez utóbbiaknak a „fegyelemért cserébe pénzt" megközelítés keretében jórészt érvényt is szereztek.

Az Európai Unión belüli javulás döntő eleme volt, hogy létrejött-e szakmai közmegegyezés, vagy sem. Emlékeztetünk arra, hogy François Hollande vagy a görög Sziríza éppen a pénzügyi szigor ellenében nyert választást. Ebben a helyzetben a tudomány által kedvelt komplex eljárások a gyakorlati alkalmazás során a zürzavar és a politikai kiskapuk fedőnevévé silányulhattak.

A témakör talán legizgalmasabb része a diszkrecionális államháztartási politika visszatérését és tartósulását övező viták fellángolása és folytonos jelenléte. Mint közismert, a hagyományos keynesi felfogás a költségvetési szimmetria alapvetésével élt. Azaz jó években nem 3 százalék alatti deficitre, hanem többlettel záró költségvetésre kell törekedni ahhoz, hogy a visszaesés idején legyen mozgástér a költekezésre. Ezt a hagyományos felfogást azonban csak a tagállamok egy része (így Németország, a balti államok, Románia, Szlovákia, Csehország és Írország) vallja és alkalmazza a gyakorlatban. Nem kérdéses ugyanakkor, hogy az Európai Unió mai konstrukciójában a pénzügyi unió lényege szerint és részleteiben is megköveteli a tagállamok azonos felfogását. Ebből adódnak az egybehangolt költségvetési politikai lépések (Wyplosz [2017]).

A költségvetési unió meghirdetése ezért semmiképpen sem jelenthette - és nem is jelenti - azt, hogy a politikum lényegét jelentő kérdéseket egy nemzetek feletti technokratikus szerv dönthetné el. Az ugyanis, hogy ki mennyit fizet és miből, a szabad társadalmak egyik legfontosabb kérdése. Ugyanakkor az is egyértelművé vált a 2007-2009-es globális pénzügyi válságra adott válaszok nyomán, hogy a közösségi pénzügyek vitele konkrétan és részleteiben is igényli azt, hogy a költségvetési politikák azonos zsánerü válaszokat adjanak.

Az egyik legfontosabb gyakorlati kérdés az volt, hogy miképp lehet megbízhatóan kiszámítani a költségvetési multiplikátor értékét. Ismeretes, hogy a görög válság mélypontján éppen az IMF elemzői csoportja állt elő azzal, hogy a görög válságot a megszorítások csak elmélyítették (Blanchard-Leigh [2013]). Ezt a véleményüket azzal támasztották alá, hogy a költségvetési multiplikátor mértéke a szokásos feltételezések duplája vagy még nagyobb is lehet. Például 1 százalékpontos megszorítás akár 4-5 százalékpontos visszaesést is kiválthat, ha a modellfeltevéseik igazak.

Nehéz lenne e bonyolult technikai és ökonometriai kérdésben igazságot tenni. Egyfelől a vita ismételten kiemelte annak a jelentőségét, hogy a közgazdasági modellek természetéből adódóan a következtetés csak az adott feltételek mellett igaz. Másfelöl a valóságot sok más is alakítja, például az intézmények hatékonysága, a kormányzat minősége vagy épp a közbizalom szintje (a görög esetben ezek mind kedvezőtlenek).

Az Európai Unió elmúlt évtizedében kialakult válságkezelési gyakorlat összehasonlító elemzése (Györffy [2018] 191-212. o.) bizonyos agnoszticizmusra ad alapot, 
méghozzá mind a föáramú közelítés (a számmisztika), mind a versengő, történetiintézményi érvelés tekintetében. Egyfelől: számos esetben erős formális intézmények híján is sikeres volt az államháztartás konszolidációja, mégpedig úgy, hogy az a gazdasági növekedést nemhogy akadályozta volna, hanem kimondottan elömozdította. Ez volt a helyzet Lettországban, Szlovákiában és Írországban. Más országokban (így például Belgiumban, Franciaországban és az Egyesült Királyságban) a kiterjedt és erős formális jogosítványok melletti intézményi elrendezés sem tudott gátat szabni a rendszeres és nagymértékü kisiklásoknak.

Különösen Franciaország, Olaszország és Spanyolország esetében vált szembeötlővé, hogy a közgazdasági és a politikai megfontolások egymással rendszeresen szembekerültek, és ezért a költségvetés kiigazítására, de különösen az adósságszabály betartására irányuló kormányzati politika rendre csődöt mondott. 2003 óta visszatérően, mondhatni, éves rendszerességű eseményként előbb az Európai Bizottság, majd a vétkes tagállamokat is tömörítő pénzügyminiszterek tanácsa (Ecofin), végül a legfőbb döntéshozó szerv, az Európai Tanács is áldását adja arra, hogy a „különlegesen kedvezőtlen körülmények halmozódására tekintettel átmeneti jelleggel” a visszaesők felmentést kapjanak az államháztartási szabályok betartásának kötelezettsége alól.

A felsorolt tagállamokban nem arról van szó, hogy az államháztartás rejtett feszültségeit kimutatják és számszerüsítik. Valójában három szerkezeti lyuk figyelhető meg. Ezek: a bankrendszer bukott hiteleinek állami átvállalása, az állami cégek veszteségeinek fedezése, végül az időskori ellátások (köztük az egészségügyiek) ténylegesen szükségessé váló költségvetési kiegészítése. Mindez messze áll a növekedést serkenteni hivatott reflálás céljától. Szembetűnő, hogy tartós növekedést a kimondottan ortodox felfogású országok értek el.

Az elemző számára a legnagyobb kihívást az egyedi mérlegelésre épülő költségvetés-politikai gyakorlat visszatérése és elméletileg bevetté válása jelenti (Coricelli és szerzőtársai [2017]). Egyfelől a válság kezelésének tapasztalatai megerősítették azt a meggyőződést, hogy a békeidőkre kialakított szabályok a valódi nehézségek idején nem alkalmazhatók. Másfelől nem kétséges, hogy minél nagyobb fokú a kötetlenség, annál nehezebb kompromisszumokat találni a különféle belpolitikai feszültségek és kihívások között lavírozó tagállami kormányok szempontjai között.

Szeretnénk kiemelni: nem az a fő baj, amit a gazdaságpolitikai elemzésekben oly gyakran emlegetnek, nevezetesen, hogy a „fegyelemért - pénzt” elve nem müködik. A valódi gondot a - közgazdasági és különösen a pénzügyi - elméletben rég ismert és bevett hitelességi probléma kiéleződése jelenti. A dél-európai országoknak mostanra annyira megrendült a hitelessége, hogy mégoly erőteljes javulás, mégoly erőteljes megszorítás révén sem állítható helyre könnyen és gyorsan.

A költségvetési unió 2012. évi meghirdetésének, valamint a közösen vállalt célok és mértékek szigorú betartatásának éppen az - lenne - az értelme, hogy a rendszeresen ellenőrzött teljesítményjavulás, valamint az ehhez nyújtott közösségi támogatás együttesen visszaadja az euróövezet némely meggyengült hitelességű országának a piaci elfogadottságát. Nem kétséges ugyanakkor, hogy ez a megoldás is csak akkor lehet sikeres, ha a játékosok a szabályok szerint játszanak. 
Tekintettel arra, hogy a szabályszegők között rendszeresen három nagy tagállam is megjelenik, amelyek mindegyikénél igazolható, hogy államháztartásuk lazasága mögött a politikai struktúra megoldatlanságai játszanak meghatározó szerepet, a költségvetési unió jórészt jelszó maradt. Nem kétséges, hogy a konjunktúra javulása teret adott a költségvetési pozíciók javulásának, és az euróövezetben az adósságráta is csökkenésnek indult: a 2014. évi csúcsról, ami a GDP 92,9 százaléka volt, 2017-re 87 százalékra mérséklődött, és az EKB előrejelzése szerint 2020-ra 80,7 százalékig csökkenhet, ami még mindig lényegesen magasabb a válság elött, 2008-ban mért 68,6 százaléknál (ECB [2017] 34-35. o.). Ugyanakkor a korábbi időszak tapasztalatai óvnak attól, hogy a javulási folyamatot adottnak tekinthessük.

Másfelől: az integráció jogrendszerének alapvetően kormányközi jellege igen erős korlátokat állít a vétkesek szó szerint vehető „megbüntetése” elé (Bickerton és szerzötársai [2015], Balázs [2017]). Kicsi a valószínűsége, hogy például a költségvetési egyezménynek megfelelően valóban akár a GDP fél százalékáig terjedő büntetést rójanak bármely tagállamra. ${ }^{7}$ Ilyen értelemben jogosan fogalmazódik meg a szabályalapú költségvetés hatékonyságát épp az európai uniós gyakorlat alapján megkérdőjelező, agnosztikus szakirodalmi álláspont (Benczes [2017]).

\section{A pénzügyi intézmények szabályozásának közösségiesítése}

Az európai bankunió végső fokon nem más, mint az egységes piac-egységes pénz maastrichti programjának befejezése. A bankunió ötlete - beleértve a közös bankfelügyeletet - még 2001-ből, a Lámfalussy-bizottságtól származik. Végül ezt csak a globális pénzügyi válságot követően sikerült tető alá hozni.

A Bizottság már 2015-ben nyilvánosságra hozta részletes tervezetét (EC [2015d]), ami szerint a bankuniót tőkepiaci unióval is ki kellett volna egészíteni. Ennek lényege a tökepiaci szabályozások egységesítése, ami által a kontinentális tökepiac - jelenleg meglehetősen csökevényes és szétszabdalt - formája egy, a vállalatfinanszírozást jobban segítő, valóban egységes intézményi keretté alakulhat át.

A 2012. júniusi tanácsi határozattal útjára indított bankunió voltaképpen az áruk és a szolgáltatások határokon átnyúló közös piacának természetes alkotóeleme. Minél erösebb és elterjedtebb a kontinentális német-francia modell, ahol az ipari és a pénzügyi vállalkozások összefonódása a norma, annál inkább technikai minimum, hogy azonos szabályok vonatkozzanak a határon átívelő banki tevékenységekre is.

A bankunió monografikus terjedelmủ elemzését da Costa Cabral és szerkesztötársai [2017] átfogó elemzései tartalmazzák. A bankunióra vonatkozó terv negyedévről negyedévre alakul - e fejleményekről az EKB és a Bizottság honlapja rendszeresen beszámol.

A bankunió voltaképp négy, egymással szorosan összefüggö, mégis különálló részterület közös szabályozását eredményezte. Az első a rendszer egésze szempontjából fontos

\footnotetext{
${ }^{7}$ A ma uralkodó neokeynesi felfogásban az is kérdéses, van-e értelme épp a visszaesés idején pótlólagos elvonást eszközölni, amit a szankció jelentene.
} 
pénzintézetek (banks of systemic relevance) központi felügyelete. Ezt az EKB-hoz telepítették, de azon belül elkülönült egységbe szervezödött, hogy a monetáris politikával adódó nyilvánvaló érdekütközések és átfedések elkerülhetők legyenek.

Az évtizedes kormányfői tanácsadó szerepből is építkező Christian de Boissieu joggal jegyzi meg, hogy ez bizonyára nem vegytiszta megoldás (Boissieu [2017] 93-94. o.). Egyfelöl az EKB felügyelöbizottsága és a közös felügyelet (Single Supervisory Mechanism, $S S M)$ kormányzótanácsa közötti elkülönülés és feladatmegosztás korántsem kézenfekvő. Másfelől az EKB kamatpolitikáját az ismert, elfogadott és nem utolsósorban alapszabályában is rögzített makroökonómiai megfontolások mellett olyan politikaiüzleti szempontok is vezérelhetik (sőt vezérlik is a nem hagyományos eszközök bevetése során), mint az, hogy a jelentősen eladósodott, törékeny egészségü, nagy nemzeti kereskedelmi bankok életét „túl magas” kamatszint ne keserítse meg.

A második elem a határokon átívelő banki tevékenységek egységes rendszer szerinti szabályozása, különös tekintettel a válsághelyzetekre. (Itt az alapelv az, hogy elsőnek a részvényesek, másodszor az adott ország költségvetése és csak harmadrészt a közös alapok állnak helyt.) Az egységes banki válságkezelési mechanizmus (Single Resolution Mechanism, SRM) részeként egy 55 milliárd eurós alap áll rendelkezésre az említett kimentések fedezetére. Az SRM 2016 januárja óta hatályos, és 143 nagy bankcsoport tartozik a hatálya alá.

Harmadikként szólni kell a bankrendszer elleni támadások (és az egyes tagállamok fiskális gyengeségét is kihasználó lépések) kivédésére alapított európai stabilitási mechanizmusról (European Stability Mechanism, ESM), amely 705 milliárd euró felett rendelkezik, de további összegeket is mozgósíthat.

Végül negyedikként szót kell ejteni az egységes európai betétbiztosítási alapról, amelynek létesítéséről 2015 novemberében határoztak, de eredmény még nem született. A Bizottság 2017. novemberi helyzetjelentése (EC [2017a]) bírálja az elörehaladás lassúságát. Ugyanakkor megállapítja, hogy szükség van a befektetési bankok közös felügyelet alá rendelésére, valamint a jelenleg kormányközi szerződésben létrehozott új megoldások alapszerződésbe illesztésére. Ezzel párhuzamosan kerülne sor az ESMnek egyfajta Európai Monetáris Alappá (European Monetray Fund, EMF) való fejlesztésére. Az ezzel kapcsolatos szakmai munkálatok előrehaladott állapotban vannak, és csupán a politikai szint jóváhagyására várnak.

Felvetődött, hogy a közös szabályokat a biztosítókra is alkalmazni kellene. Ezen túlmenően megfogalmazódik a kormányzatok által kibocsátott kötvényekkel fedezett részvények kibocsátásának gondolata is. Az utóbbi kapcsán német-holland-szlovák ellenállás tárgya lesz az, hogy miképp kerülhető el a felelőtlen kiadások végeredményben fedezet és ellenőrzés nélküli „közösségiesítése”.

Nem ejtettünk szót arról, ami a bankunió és a közös monetáris politika szempontjából a legnagyobb jelentőségü lépés, az Európai Központi Bank lényegi átalakulásához vezető új szerepváltásáról. Mario Draghi elnök sokat idézett 2012. júliusi kijelentése óta - amely szerint az EKB „bármit kész megtenni az euró megmentése érdekében" - alapvető változások mentek végbe. Először az EKB a másodpiacon kezdett vásárolni a gyengélkedő országok államkötvényéből, utóbb - 2014 óta - pedig már az elsődleges piacon is megjelent. 
Az EKB az alapszabályában foglaltaktól és első másfél évtizedes gyakorlatától egyaránt teljesen eltérő eszközrendszert vetett be és alkalmaz széles körben. Ki kell emelni ezek közül a nyíltpiaci műveletek új kategóriáját, amely három elemből áll: a hároméves refinanszírozási ügyletekből, a bankok hitelezését élénkíteni hivatott - akár négyéves lejáratú - célzott hitelinjekciókból, valamint az eszközvásárlási programból, amelyben két százalék alatti kamatköltség mellett vesznek állampapírokat. 2017 júniusában megállapodás született arról, hogy az EKB sürgősségi likviditási támogatási (Emergency Liquidity Assistance, ELA) program keretében közvetlenül is nyújthat vészhelyzeti hiteleket az euróövezet pénzintézeteinek. ${ }^{8}$ Emellett a TARGET2 elszámolási rendszerben a csődközeli időkben jelentős likviditást - egyes időszakokban és országoknak több tízmilliárd eurót - is juttattak. Bár az eszközvásárlási program a 2017. évi havi 80 milliárd euróról 2018-ra 30 milliárd euróra csökkent, miközben az Egyesült Államokban már 2016-ban kivezették a programot.

A nem hagyományos eszközök bevetése és saját szerepének újraértelmezése az EKB-t teljes értékủ jegybankká - így nem utolsósorban végső hitelezővé is - alakította. Ebbe még a pénzügyi felügyelet is beleértendő.

Nem kérdéses, hogy mindeme úítások két válságra adtak választ. Egyfelől az euróövezet döntéshozói szerint a térség állandó deflációs veszélyben volt. Másfelől a lépések jelentős részben rögtönözve, a válságelhárítás keretében ad hoc politikai alkuk keretében jöttek létre (Brunnermeier és szerzőtársai [2016]). Aligha véletlen, hogy az újítások kivétel nélkül kormányközi egyezményekben jelentek meg, és az EU-alapszerződésbe történő integrálásuk nem sikerült. Mindenesetre az idézett kötet visszatérő eleme az, hogy az EU csúcsvezetői mindenáron el kívánták kerülni egyfelől az euróövezet szétesését, másfelől pedig az Egyesült Államokon végigsöprő pénzügyi válságot. Igaz, az amerikai megoldás elvezetett a piactisztuláshoz, sőt a kincstár több tízmilliárdos haszonnal zárt (Calomiris-Khan [2015]), míg Európában a toxikus követelések is megmaradtak, és a versenyképtelen banki szerkezet sem változott.

Mit jelent az EKB gyakorlata a központi bank politikai elszámoltathatósága híján? Kétségtelenül jelentős újraelosztást és aránytalan, kevéssé ellenőrzött hatalmat, amit a technokratikus kényszer igazol. Láttuk, hogy a görög/spanyol/olasz válsághelyzet idején jelentős újraelosztás történt, lényegében átláthatatlan módon és az ismert szabályok megkerülésével, mindenféle biztosíték nélkül (ami az ismétlődést kizárná).

$\mathrm{Az}$ említett példák bizonyára indokolnák az EKB olyan típusú ellenőrzését, mint amit a Kongresszus két háza gyakorol a Fed felett az Egyesült Államokban. Az EKB azonban nem teljes értékü jegybankként jött létre, hanem kizárólag egy szabálykövető monetáris politika vitelére. Ez utóbbihoz - éppen a diszkrecionalitás és a költségvetési, valamint az újraelosztási hatások rendszerszintü kizárása miatt - nincs szükség hasonlóan szoros politikai elszámoltathatóságra. Ez azonban meghaladottá vált a válságot követő évtizedben.

Az újítások azon részénél, amelyek vélhetően semmiképpen sem kifogásolhatók - ilyen az ESM és az SRM, valamint a közös bankfelügyelet és a még létrehozandó

\footnotetext{
${ }^{8}$ Minderről az EKB honlapján a monetáris politikát részletesen ismertető elemző anyagok olvashatók: www.ecb.europa.eu/mopo/implement/html/index.en.html.
} 
betétbiztosítás -, már jelenleg is az EU 2014-2020 közti többéves költségvetési keretét elérő összegekről döntenek szakértői csoportok. Ekkor még nem szóltunk arról, hogy az EKB úgynevezett stresszteszteket dolgoz ki, vagyis modellszámításokat készít egy esetleges válsághelyzetre, és jelzi, mely bankoknál állna fönn tőkehiány. Ezek a gondolatkísérletek jelentős tőkeemeléseket indukálnak.

Gyakorlati és szabályozási szempontból ugyanilyen könnyen belátható, hogy a felsorolt négy terület nem véletlenszerüen és nem esetlegesen különül el egymástól. Az a tény, hogy a tőkepiaci unióra vonatkozó munkálatok külön pályán indultak el, már mutatja, hogy az, ami hasonló, nem feltétlenül ugyanaz. A biztosítás hasonlóképpen nem ok nélkül különül el a banki tevékenységtől évszázadok óta. A befektetési alapokat hagyományosan az Egyesült Államokban is 2000-ig „kínai fal" választotta el a banki tevékenységtől.

Ugyanakkor a pénzügyi közvetítés univerzálissá válásával értelmes lehet egységes rendben szabályozni a terület egészét. Ekkor kérdéses, hogy mi késztetheti a szabályozó hatóságokat jogköreik feladására. A bankunió esetében a terület válságainak halmozódása indította el ezt a folyamatot (Kudrna [2016]). A tökepiaci unió esetében a jelenlegi közös költségvetésből elérhető összegek kétezerszerese mozdulhat meg. Ez euróban számolva a Bizottság anyagai szerint többmilliárdos megtakarítást hozhat csupán a tranzakciós költségekben, és eddig elképzelhetetlen összegü és összetételü új forrást mozgathat meg új befektetések finanszírozására.

\section{A tőkepiaci unió csak elmélyíti a már müködő bankuniót}

A fenti vázlatos áttekintés már kellőképpen igazolhatta a kételkedők számára is, hogy az Európai Unió alapjaiban alakult át a 2008-2012-es időszakban, és hogy a pénzügyi integráció elmélyülése új minőséget ért el, mi több: feltartóztathatatlanul gyorsul a brit kilépési szándék bejelentését követően. Egyfelől jelentősen megnőtt a nemzetek feletti, technokratikus döntések súlya a kormányköziek ellenében. ${ }^{9}$ Míg a politikában a kormányköziség szilárdan tartja magát, pénzről egyre inkább független szabályozó hatóságok döntenek. Ráadásul a politikai színtéren középpontba állított kohéziós és mezőgazdasági kifizetések összefüggésében az egyoldalú transzferek (a fejlesztési segélyek) kapcsán rég ismert kételyek ${ }^{10}$ a hazai botrányokból is ismert módon és okokból még fel is erősödtek.

Mindez azt jelenti, hogy az euróövezetben új minőségü, szupranacionálissá mélyült integráció jött létre. Ez egyértelmű az új minőségű, korlátlan véghitelező és célzottan, költségvetési jelleggel beavatkozó EKB, a közös pénzügyi felügyelet, a közös

\footnotetext{
${ }^{9}$ Hagyományosan az integráció irodalmában a közösségi módszert állítjuk szembe a kormányköziséggel. Ugyanakkor azokban az esetekben - mint mondjuk az ESM/EMF vagy a funkcióját megváltoztató $\mathrm{EKB}$-, amikor a Tanács döntését követően a közvetlen politikai alkuk/befolyásolás lehetősége kizárt, a döntés depolitizált, szakmai, ha tetszik, technokratikus, abban az értelemben, ahogy a föszöveg az EKB-ra értelmezi.

${ }^{10}$ Nemrégiben Bod Péter Ákos tett közzé elmélettörténetileg megalapozott gondolatmenetet e tárgykörben, kiemelve az ellentételezés nélküli pénzinjekciók szükségképp káros hatását (Bod ([2017]).
} 
bankszanálás, valamint az ESM/EMF esetében. Más esetekben - így a betétbiztosítás, a szélesebb pénzügyi felügyelet vagy ma még a tőkepiac szabályozása esetében - ez a folyamat még csak megindult, de messze nem zárult le. A tagállamok egy része ebből - lényegében saját döntésre - kimaradt. Nem vettek részt az új szabályok megalkotásában, és így majd nem élvezik az ezáltal létrejött védőernyőt, és nem férnek hozzá a szó szerint két nagyságrenddel megnövekvő közös tőkepiachoz sem.

Rachel Epstein joggal és meggyőzően érvel amellett, hogy a bankfelügyelet nemzetek feletti szintre kerülése, a részvényesek kötelező bevonása meggyengítette a kontinetális piacgazdasági modell ${ }^{11}$ egyik alapvonását, a tulajdonos és szabályozó állam és a magánbankok közti meghitt viszonyt (Epstein [2017] 128-140. o.). Márpedig ez meghatározó vonása volt az európai piacgazdasági modelleknek az amerikaival és a brittel szemben (Farkas [2017]).

Az EU-ban a bankunióval létrehozott egységes banki válságkezelési mechanizmus (SRM) is a megelöző évtizedben folytatottnál sokkal inkább piacelvü megoldásokat ír elő. Mindez hihetetlen mértékben megerősítette a közös valutaövezet válságtürő képességét. És megfordítva: a dolog természeténél fogva megsokszorozta mindazok kitettségét és kockázatát, akik ebből a sokszálú védőhálórendszerből ilyen vagy olyan okból kimaradtak, megőrizve „monetáris politikájuk szuverenitását és mozgásterét”.

$\mathrm{Ez}$ a fejlemény egyszerre két fontos rendszeralkotó elemet is jelent. Egyrészt, a bankunión belül sokkal inkább piacelvü és technokratikus gyakorlat alakul ki mind békeévekben, mind a válság időszakában. Másrészt, aki kimarad, az lemarad - egyebek mellett az EKB által teremtett korlátlan likviditásból, az ESM/EMF biztosította védőpajzsból és az SRM biztosította puha átmenetből. A közös pénzintézeti/felügyeleti szabályozás (Single Supervisory Mechanism, SSM) hatókörén kívül kerültek bankrendszere és valutája ellen bizonyára sokkal kisebb költséggel lehet támadást intézni. Könnyebb az ellenséges felvásárlás is, és korántsem csak a pénzügyi szférában. És nem utolsósorban: szó szerint minden veszteséget az adott állam polgárai viselnek. Lélektani oldalról nézve: a közös védőernyő alá került intézményeket nemigen érdemes megtámadni, viszont különösen megnőhet az étvágy a nem védett, kívülállók elleni spekulációra.

Érdemes kiemelnünk azt, hogy az európai monetáris és költségvetési integráció elmélyülésével átfogó, koherens, szankciókkal is megerősített, részletes eljárási rend jött létre. Ennek főbb összetevőit korábbi írásunk részletezi (Csaba [2014]). Az újítások közül kiemelendő a költségvetési számok előzetes egyeztetését a megalapozó intézkedésekkel együtt szabályozó európai szemeszter, az immár szankciókkal súlyosbított túlzottdeficit-eljárás, valamint a külgazdasági-pénzügyi dimenziót elötérbe állító túlzott egyensúlytalansági eljárás. ${ }^{12}$ Mindegyik területen a közös alapok megvonásával sújthatják a vétkeseket, különösen, ha a kisiklás ismétlődik. Válság esetén ez a nemze-

\footnotetext{
${ }^{11}$ A kapitalizmus változatairól (varieties of capitalism, VoC) szóló irodalomban ez a koordinált piacgazdaság, a komparatív közgazdaságtanban az állam vezérelte piaci modell. Részletes egybevetést és áttekintést ad Farkas [2017] monográfiája.

${ }^{12}$ Ugyanakkor nem volt kérdéses már elözetesen sem az, hogy az eljárások és az intézmények inkább csak szükséges, semmint elégséges feltételei a fegyelmezett államháztartásnak az EU-tagállamaiban is (Jankovics [2012]).
} 
tek feletti és technokratikus eljárási rend szigorú keretek közé szorítja, hogy ki mit és hogyan tehet, és ekkor válik még fontosabbá, hogy valaki a „kerítésen kívül vagy belül van". Christian de Boisseiu joggal jegyzi meg, hogy bár az európai pénzügyi integráció különféle új kereteit létrehozó kormányközi egyezményekben rituálisan szerepel az, hogy nem EMU-tagok is beléphetnek, valójában nehéz elképzelni olyan gyakorlatot, hogy egy tagállam, mondjuk, a bankunióban vagy a tökepiaci unióban úgy vehessen részt, hogy közben nem használ eurót (Boisseiu [2017] 99. o.).

Ezért egyfelől rokonszenvezünk azzal a felfogással, ami jogi érveléssel azt hangsúlyozza, hogy az egységes piac és egységes szabályozás megőrzendő akkor is, ha a nyílt együttmüködési módszer alkalmat ad arra, hogy lúdcsapatként változó geometriában társuljanak a tagok (Martonyi [2017]). Ugyanakkor meghaladottnak tűnik érvelésének ama része, amely kifejezetten óv attól, hogy az elmélyülő pénzügyi/tőkepiaci unió elkülönült és tartós intézményi struktúrává váljon. A cikk elején és a kifejtésben idézett lépésekkel ez már megtörtént. Sőt láthatóan 2019-2020-tól további szabályozási lépések történnek, amelyek mind csak a valutaunióban való részvétel mellett értelmezhetők, mert a részvevőkre vonatkoznak, a kívülállókra nem.

A realitások alapján ketté kell bontanunk elöretekintésünket. Egyfelől: üdvözöljük, hogy az EU vezető szervei a jó időket, a jó konjunktúrát és a többéves pénzügyi keret kialakulása körüli vitákat arra is felhasználják, hogy az EU jövőjét több változatban vázolják fel. Külön is üdvözlendő a Bizottság 2017. júniusi anyaga ( $E B$ [2017], lásd még és EC [2017b]), ahol a számmisztikát megelőzően felteszik a korábban mindig kerülgetett kérdéseket, beleértve a több vagy kevesebb „Európa”, azaz közösségi döntési hatáskör, a több vagy kevesebb költés, a több egységesítés vagy több különutasság kérdéseit. ${ }^{13}$

Másfelől: világosan látható, hogy épp a négy legnagyobb tagállam politikai struktúrája mélyreható válságjelenségekkel szembesült. Németországnak - a háború utáni évtizedekben elöször - hónapokon át nem volt kormánya, és a legnagyobb erők közötti bizalmatlanság beteges mértékűvé vált. Olaszországban az öröklött struktúrákkal szemben álló, de valós pozitív alternatívát papíron sem képviselő Öt csillag mozgalom és a széttöredezett pártszerkezet nem teremti meg a kemény kormányzás, a költségvetési kiigazítás alapját. Stabil kormányzásra sem lehet számítani hosszabb időn át. Spanyolország a katalán népszavazás és a helyi pénzügyi rendszer megoldatlanságai okán nem tud kezdeményezni. A spanyol pártszerkezet is széttöredezett, a kormány többsége csekély és borulékony, számos régió (a Baszkföld, Andalúzia) is feszültségek forrása, mint ahogy a helyi hatalmak alárendeltségében müködő takarékpénztári rendszer is. Franciaországban pedig Emannuel Macron személyén kívül nagyon kevés tartja össze az En Marche! mozgalmat, kormányzati tapasztalata kevés szereplőnek van. Minden reformkezdeményezés azonnali társadalmi ellenállást vált ki, ami határokat szab a francia Európa-politika mozgásterének is.

Mindezek alapján szorgalmazzuk, de egyáltalán nem jelezzük elöre, hogy az európai pénzügyi integráció új formái, köztük a tőkepiaci unió keretében már kimunkált - és belátható időn belül még kiegészülő - megoldásokat a maguk teljességében átültessék

${ }^{13}$ A többéves költségvetés dilemmáit összegzően ismerteti Kengyel [2016]. 
az Európai Unió alapvető jogi és politikai intézményrendszerébe. Ennek hiánya, mint láttuk, számos belső ellentmondás forrása marad a jövőben is. Ezek közül a kívül maradók számára különösen kellemetlennek bizonyulhat, hogy egy előbb-utóbb jelentkező pénzügyi válságban nem tudnak mire támaszkodni.

A tőkepiaci unió ma még nem valóság. Írásunk elején hivatkoztunk a nem kevesebb, mint 12 (sic!) bizottsági jogszabálytervezetre, amelyekböl öt esetben folyik a részletek vitája, három esetben megállapodásra is jutottak. Mint a szabályozás kérdéseit elméleti és technikai síkon egyaránt mélyrehatóan elemző Douadyés szerzötársai [2017] kötetből kitünik, e téren mind technikai, mind felfogásbeli eltérések vannak a tagállamok között. Ezek a konkrét esetben a kockázatok megosztását és mérséklését eltérő sorrendben, más technikákkal és a nemzeti/nemzetközi teherviselés más-más arányával képzelik el. Mivel éppen ezek a szempontok hátráltatták a bankunió megalakítását is jó másfél évtizeden át, borítékolható, hogy a Bizottság által szorgalmazott gyors és átfogó megoldásra egyhamar nem kerül sor (egyébiránt a két szempont is üti egymást). Ugyanakkor nem kétséges, hogy a tőkepiaci unió nem távlati, ködös cél - mint, mondjuk, a lisszaboni stratégia volt -, hanem olyan konkrét, operatív gazdaságszabályozási megoldás, amely belátható időn belül új dimenziót nyit meg az európai integráció fejlődésében. Ha a bevezetőben említett nagyságrendek helytállók, az európai gazdasági növekedés finanszírozásának egészen új léptéke és csatornája nyílik meg az egységes szabályozás révén.

Az euróövezettől magukat ilyen-olyan okból távol tartó EU-tagállamoknak dinamikájában nézve még súlyosabb hátrány az, hogy kimaradnak az egységes árupiacot és a valutáris, valamint a bankuniót kiteljesítő közös, egységes szabályok szerint müködő tőkepiacból. Minél inkább elismerjük azt a sokoldalúan igazolt tényt (van Ark és szerzőtársai [2013] 309-314. o.), hogy Európa immár bő négy évtizede megfigyelt lemaradásának egyik fő tényezője az innovációk finanszírozását segítő tőkepiac sekély és szétaprózódott volta, annál súlyosabbnak kell láttatnunk a kimaradás költségeit, különösen a hosszabb távon halmozódókat, amelyek a termelékenység és a megújulási képesség lemaradásában anyagilag is és szervezetileg már jelenleg is testet öltenek.

Lehet azon morgolódni, hogy az európai pénzügyi integráció révén kialakított új szabályok némelyike vagy akár egésze nem felel meg a közkeletű demokráciaértelmezésnek, mert végsö fokon nem az összes szereplő preferenciáinak arányos és átlátható, ellenőrizhető összesítésével jött létre, és a létrejött elrendezésről döntést hozók végső fokon nem számoltathatók el úgy, mint egy részvénytársaság vezetői. Ugyanakkor nem kérdéses, hogy az e cikkben taglaltak jórészt befejezett ténynek tekintendők. Tanulságos az a felismerés, hogy az unió elhagyása még a kétségbeejtő, sőt sok tekintetben kilátástalan helyzetü görög gazdaság számára sem volt (és nem lesz) valódi választási lehetőség (Györffy [2017]).

Kétségtelen, hogy az európai közösség egész történetében folytonosan a meg nem valósult tervek és az elméletileg felemás megoldások világában működött. Éppen ezért nem gondoljuk azt, hogy az Európai Unió rendszerválságban lenne, és hogy kilépések sora állítaná le azt a vonatot, amely láthatólag feltartóztathatatlanul és gyorsuló sebességgel halad előre az integráció pénzügyi vonalán, mit sem törődve a politikai széttagoltsággal. A nem tiszta megoldás nem feltétlenül müködésképtelen, a nem 
optimális elrendezés az Európai Unióban gyakran a politikailag még éppen lehetségest jelentheti, mint ahogy a három princetoni professzor föntebb idézett munkájában szemléltette (Brunnermeier és szerzötársai [2016]).

A legvalószínübbnek ezért az alapváltozat tekinthető, amelyben a részletek folytonos változtatása mára válaszúthoz vezetett. Ebben a keretben a partvonalra szorultak előtt két út áll. Az egyik az, hogy megteszik a valutauniós tagsághoz szükséges lépéseket ${ }^{14}$ - már csak azért is, hogy a cikk elején említett, a tőkepiaci uniós szabályok által terelt, gigantikus méretű beruházásáramlásból ki ne szoruljanak. A másik, hogy vállalják: döntési önállóságuk megörzése fejében lemondanak e hatalmas beruházási forrásokról, és elfogadják az ebből adódó, tartósan alacsonyabb potenciális és trendértékü növekedést, ami a ma ismert irányzatok fényében történelmi léptékben is meglehetősen aggasztó (Halmai [2018b]).

\section{Hivatkozások}

Bajusz Anna [2015]: A tagállamok és az Európai Unió közös költségvetése. Miért nem alkalmas a költségvetési nettó pozíció az integrációs előnyök mérésére? Külügyi Szemle, 14. évf. 3. sz. 122-140. o.

BALÁzs PÉTer [2017]: Az Európai Unió külpolitikája. Wolters Kluwer, Budapest.

BenCzes István [2017]: Európa válaszúton. Szabályok vagy közös költségvetés? Megjelent: Kálmán János (szerk.): Állam - válság - pénzügyek. Gondolat Kiadó, Budapest, 293-317. o. Bernanke, B. [2017]: Volt merszünk cselekedni! Napvilág Kiadó, Budapest.

Bickerton, Ch. J.-Hodson, D.-Puetter, U. (szerk.) [2015]: The New Intergovernmentalism: States and Supranational Actors in the Post-Maastricht Era. Oxford University Press, Oxford-New York.

Blanchard, O.-Leigh, D. [2013]: Growth forecast errors and fiscal multipliers. American Economic Review, Vol. 103. No. 3. 117-120. o. https://doi.org/10.1257/aer.103.3.117.

Blanchard, O.-Rajan, R.-Rogoff, K.-Summers, L. (szerk.) [2016]: Progress and Confusion: The State of Macroeconomic Policy. The MIT Press, Cambridge, MA-London.

Bod Péter Á кos [2017]: Segély vagy kereskedelem visz elöbbre? Bauer Péter szellemi öröksége. Magyar Szemle, Új folyam, 26. évf. 9-10. sz.

BoIssiau, CH. DE [2017]: The Banking Union revisited. Megjelent: Douady és szerkesztötársai [2017] 85-103. o.

Brunnermeier, M.-James, H.-Landau, J-P. [2016]: The Euro and the Battle of Ideas. Princeton University Press, Princeton, N. J.

Calomiris, Ch.-Khan, U. [2015]: An assessment of the TARP assistance to financial institutions. Journal of Economic Perspectives, Vol. 29. No. 2. 53-80. o. https://doi.org/10.1257/ jep.29.2.53.

Coricelli, F.-Fiorito, R.-Molteni, F. [2017]: Discretionary fiscal policy and recessions. Megjelent: Ódor (szerk.) [2017] 540-578. o.

Csaba László [2014]: A költségvetési és a bankunió dilemmái az Európai Unióban. Megjelent: Fekete Balázs-Horváthy Balázs-Kreisz Brigitta (szerk.): „A világ mi magunk vagyunk." HVG-Orac, Budapest, 96-109. o.

\footnotetext{
${ }^{14}$ Lásd erröl Palánkai Tibor [2015] írását.
} 
Da Costa Cabral, N.-Gonçalves, J. R.-Cunha Rodrigues, N. (szerk.) [2017]: The Euro and the Crisis: Prospects for the Eurozone as a Monetary and Budgetary Union. Springer Verlag, New York.

Douady, R.-Goulet, C.-Pradier, Ph.-Ch. (szerk.) [2017]: Financial Regulation in the EU: From Resilience to Growth. Palgrave Macmillan, London.

EB [2017]: Vitaanyag az Európai Unió pénzügyeinek jövőjéről. Európai Bizottság, COM(2017) 358 , június 28. https://ec.europa.eu/commission/sites/beta-political/files/reflection-papereu-finances_hu.pdf.

EC [2015a]: Action plan on building a capital markets union. European Commission, Brüsszel, https://ec.europa.eu/info/publications/action-plan-building-capital-markets-union_en.

EC [2015b]: Capital Markets Union. A plan to unlock funding for Europe's growth. European Commission, Brüsszel, https://ec.europa.eu/info/business-economy-euro/growth-andinvestment/capital-markets-union_en.

EC [2015c]: Az öt elnök jelentése: „Az európai gazdasági és monetáris unió megvalósítása”. Június 22. https://ec.europa.eu/commission/sites/beta-political/files/5-presidentsreport_en.pdf.

EC [2015d]: Building a Capital Markets Union. A Green Paper. European Commission, Brüsszel, http://ec.europa.eu/finance/consultations/2015/capital-markets-union/docs/ green-paper_en.pdf.

EC [2017a]: Communication on Completing the Banking Union. European Commission, Brüsszel, 11.10.2017 COM(2017) 592 final. http://ec.europa.eu/finance/docs/law/171011communication-banking-union_en.pdf.

EC [2017b]: MFF post 2020. European Commission, Brüsszel, http://ec.europa.eu/budget/ mff/index_en.cfm.

ECB [2017]: Fiscal developments. Economic Bulletin, No. 8. https://www.ecb.europa.eu/pub/ pdf/ecbu/eb201708.en.pdf.

Epstein, R. [2017]: European Banking Union: Weakening of Bank-State Ties. Megjelent: Epstein, R.: Banking on Markets. Oxford University Press, Oxford-New York, 125-162. o.

FARKAs BeÁta [2017]: Piacgazdaságok az Európai Unióban. Akadémiai Kiadó, Budapest.

GYőrfFY DóRA [2017]: Görögország a monetáris unióban: a kilépés hiábavalósága. Magyar Tudomány, 177. évf. 1. sz. 24-34. o.

GYőrfFy Dór A [2018]: Trust and Crisis Management in the EU: An Institutionalist Account of Success and Failure in Program Countries. Palgrave Macmillan, London.

Halmai Péter [2018a]: Új geometria: „teljes” gazdasági és monetáris unió felé? Megjelent: Halmai Péter (szerk.): Tagállami integrációs modellek. Dialóg Campus, Pécs, megjelenés alatt.

Halmai PÉter [2018b]: Az európai növekedési potenciál eróziója. Közgazdasági Szemle, 65. évf. 2. sz. 122-160. o. https://doi.org/10.18414/ksz.2018.2.122.

JaNKOvics LÁszLó [2012]: Független fiskális intézmények. Köz-Gazdaság, 7. évf. 1. sz. 147-164. o. Kengyel Ákos [2016]: New headings - old problems: The evolution and future of the EU budget. Intereconomics, Vol. 51. No. 2. 100-106. o. https://doi.org/10.1007/s10272-016-0584-0.

Kudrna, Z. [2016]: Financial market regulation: Crisis-induced supranationalization. Journal of European Integration, Vol. 38. No. 3. 251-264. o. https://doi.org/10.1080/07036337. 2016.1140153.

Macchiarelli, C. [2017]: European monetary integration and the EU-UK relationship. Megjelent: Campos, N. F.-Coricelli, F. (szerk.): The Economics of UK - EU Relations: From the Treaty of Rome to the Vote for Brexit. Palgrave Macmillan, London, 79-118. o. 
Martonyi János [2017]: Differentiation or disintegration: Rethinking and preserving the European Union. Hungarian Review, 8. évf. 5. sz.

Ódor Lajos (szerk.) [2017]: Rethinking Fiscal Policy after the Crisis. Cambridge University Press, Cambridge-New York.

Ódor LAJOS-P. KIss GÁBOR [2017]: Lost in complexity: Towards a decentralized and depoliticized fiscal framework in Europe. Megjelent: Ódor (szerk.) [2017] 189-231. o.

PalÁnKai Tibor [2015]: The introduction of the Euro and Central Europe. Economics and Sociology, Vol. 8. No. 2. 51-69. o. https://doi.org/10.14254/2071-789x.2015/8-2/5.

Van Ark, B.-O’Mahony, M.-Timmer, M. P. [2013]: Europe's productivity performance in comparative perspective: Trends, causes and projections. Megjelent: Prasada Rao, D. S.van Ark, B. (szerk.): World Economic Performance: Past, present and Future. E. Elgar, Cheltenham, 290-316. o.

Wyplosz, CH. [2017]: Fiscal discipline in a monetary union without fiscal union. Megjelent: Ódor (szerk.) [2017] 167-188. o. 